\title{
PEMANFAATAN JERAMI SEBAGAI PRODUK KREATIF NON INDUSTRIAL SEBAGAI DASAR PERTIMBANGAN DESAIN
}

\author{
Dharsono ${ }^{1^{*}}$, Sumarno ${ }^{2}$, N.R. Ardi Chandra ${ }^{3}$ \\ 1, 2, 3 Institut Seni Indonesia (ISI) Surakarta, JI. K.H Dewantara No. 19, Kentingan, Jebres, Surakarta. \\ Email: eyangdharso@gmail.com., sumarnoisi.ska05@gmail.com., nracandra@gmail.com
}

\begin{abstract}
Design plays an important role for product creation to have high aesthetic and economic value as an effort to empower the community. Important to be considered in the design is the ability of human resources and natural resources related to straw. Therefore identifying the use of straw for various products and production techniques becomes important for planning in the development of industrial design. The research method is to use descriptive analytical research with data sources in the form of written, oral, related images. Data collection techniques with observation and data validity with data triangulation. Data analysis uses interactive analysis. The result of the discussion is that straw has been utilized as a variety of creative products, however the production is not yet industrial and there is no design development. Production capabilities and production techniques that develop in the community are important as a basis for the development of handicraft products and industrial furniture.
\end{abstract}

Keywords: strawrice, design, crafts and furniture.

\section{PENDAHULUAN}

Padi telah dibudidayakan oleh masyarakat Indonesia sejak zaman dahulu, karena nasi merupakan makanan pokok masyarakat Indonesia pada umumnya. Makanan pokok non nasi di Indonesia hanya terdapat di Madura (jagung), Papua (sagu). Perkembangan terkini bahkan juga bergeser menjadi nasi. Berbagai jenis tanaman didatangkan, dibudidayakan atas pengembangan/dibawa oleh bangsa penjajah. Merujuk pada cerita Dewi Sri yang telah berkembang turun-temurun dengan demikian tanaman padi telah dibudidayakan oleh masyarakat Indonesia sejak zaman dahulu.

Bagian vegetatif tanaman padi meliputi akar, batang, dan daun, sedangkan bagian generatif berupa malai dari bulir-bulir padi (Kuswanto, 2007). Bulir padi atau gabah merupakan komuditas utama dari tanaman padi selanjutnya untuk diolah menjadi beras. Hasil tanaman padi selain beras, oleh karena itu dianggap sebagai limbah. Hal ini karena nilai ekonomi atau nilai manfaatnya yang rendah. Jerami dan sekam merupakan sisa pemanenan padi yang disebut dengan limbah.

Jerami sisa hasil panen padi secara umum hanya dibakar oleh para petani. Jerami hasil panen petani sebesar $62 \%$ jerami dibakar dan hanya sekitar $38 \%$ dimanfaatkan sebagai pakan ternak atau untuk kepentingan industri (Situmeang, 2010). Jerami sebagai sisa limbah pemanenan pada dasarnya bisa dimanfaatkan dan telah dimanfaatkan untuk berbagai keperluan hidup manusia. Pemanfaatan yang dimaksud yakni mulai dari yang bersifat personal, ritual, maupun fungsional. Pemanfaatan jerami secara tradisional oleh para petani, dimanfaatkan sebagai pakan kering manakala persediaan pakan menipis atau pada musim kemarau datang. Jerami selain sebagai pakan juga sebagai alas kandang ternak, atap rumah, panahan. Jerami kini juga telah dimanfaatakan sebagai bahan, bioetanol, bahan kosmetik, bahan minuman tradisional, mulsa jerami, media tumbuh budidaya jamur, pakan, pupuk kompos dan atau pupuk organik.

Pemanfaatan jerami untuk karya seni dan produk kreatif juga cukup banyak. Namun demikian pemanfaatan jerami bersifat masal dan industrial masih sangat terbatas. Kondisi ini sehingga masih terdapat over supply antara jerami dan kebutuhan industri. Oleh karena itu jerami dimanfaatkan untuk apa sajakah pada karya seni, kerajinan maupun produk industri. Identifikasi pemanfaatan jerami untuk berbagai produk mengetahui teknik produksi apa sajakah yang telah dikembangkan dalam pemanfaatan jerami. Identifikasi diperlukan untuk pengembangan produk kerajinan sebagai upaya penyerapan limbah jerami dalam volume yang lebih tinggi. Industri kerajinan dan mebel 
berbasis limbah jerami penting dikembangkan karena nilai tambah dan penyerapan tenaga kerja bersifat nonformal yang cukup tinggi.

\section{METODE PENELITIAN}

Penelitian ini merupakan penelitian yang bersifat deskriptif analitis terkait dengan pemanfaatan jerami teknik produksi yang berkembang di masyarakat. Pengeta-huan tersebut selanjutnya sebagai dasar bagi desainer dalam perencanaan dalam desain produk kerajinan dan mebel. Sumber data, berupa tulisan, lisan, gambar yang terkait dengan jerami dan pemanfaatan jerami. Teknik pengambilan data dengan observasi terkait dengan jerami dan pemanfatan jerami utamanya terkait dengan penulisan atau teks. Validitas data dengan triangulasi data. Analisis data menggunakan analisis interaktif dimana dilakukan reduksi data, display data, dan penarikan kesimpulan pada sebuah siklus.

\section{HASIL DAN PEMBAHASAN}

Jerami padi merupakan bahan yang secara kimia merupakan senyawa berlignoselulosa. Menurut Saha (2004) komponen terbesar penyusun jerami padi adalah selulosa (35-50 \%), hemiselulosa (20-35\%) dan lignin (10-25\%) dan zat lain penyusun jerami padi. Jerami bersifat ulet, berbentuk bulat memanjang, berdiameter pada konsisi basah ujung bawah sekitar $4-7 \mathrm{~mm}$ dan bagian ujung sekitar $2 \mathrm{~mm}$. Batang jerami beruas dan berongga dengan panjang ruas rapat dan semakin jarang pada bagian atas. Warna jerami berwarna hijau kecoklatan untuk jerami basah dan berwarna kuning bersih untuk jerami kering. Jerami mudah kering dengan dijemur sekitar $2-3$ hari di atas panas matahari. Berat jenis jerami sangat rendah dan dan mudah terbakar.

Sifat dan kareakter jerami tersebut sehingga jerami dimanfaatkan untuk berbagai keperluan hidup manusia. Produk yang dihasilkan baik bersifat dua dimensi atau tiga dimensi. Jerami sebagai bahan utama maupun sebagai bahan pendukung atau pelengkap.

a) Jerami sebagai bahan baku untuk alat permainan yakni wayang, sompretan (dremenan), panahan, patung, burung-burungan.

b) Jerami keperluan pertanian dan peternakan yakni sebagai orang-orangan sawah, sarang ayam atau burung, packing telur,

c) Produk kerajinan dan souvenir, kalung, gelang dan sandal, sapu, lukisan, tas, nampan, dan hiasan dekoratif, sebagai bahan pendukung/utama produk kerajinan dan furniture.

d) Jerami juga dapat dimanfaatkan sebagai bahan bubur kertas dan kertas art paper.

e) Jerami untuk dinding dan atap rumah atau gubug.

f) Jerami dimanfaatkan untuk sebagai properti seni pertunjukan.
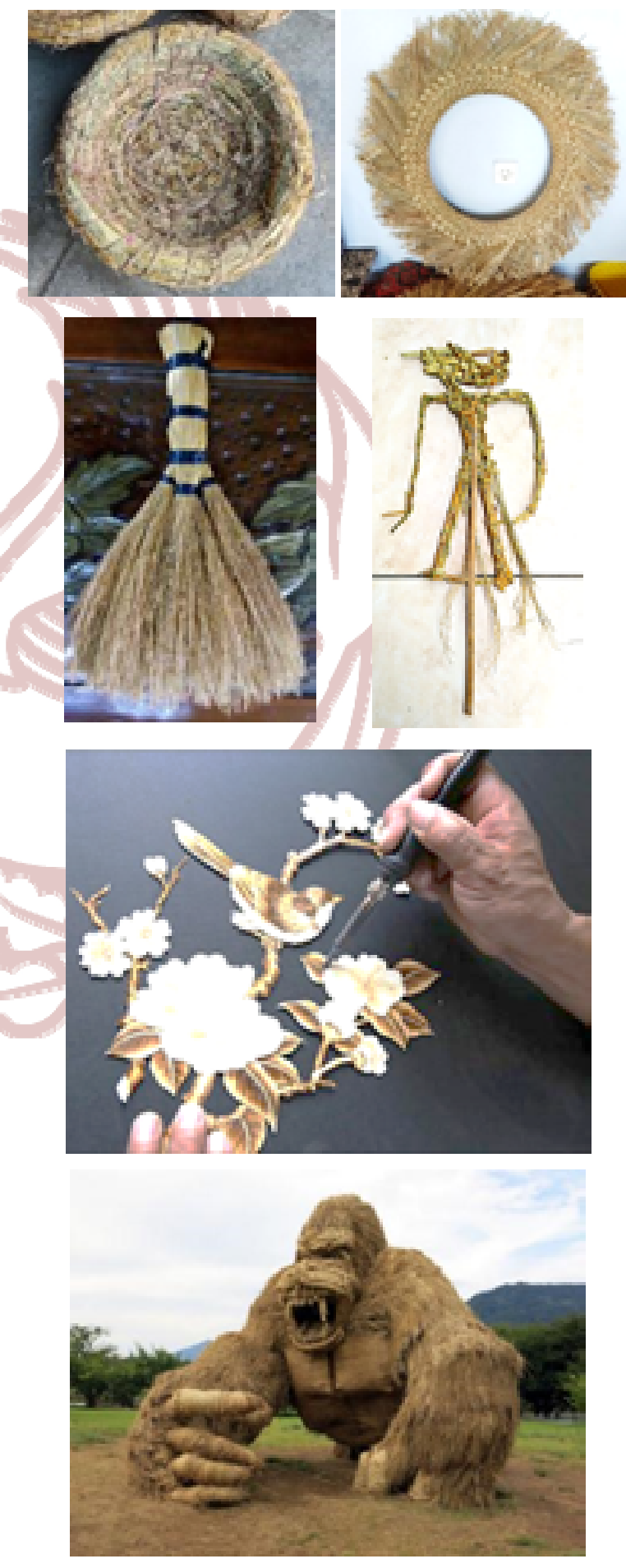

Gambar 1: Macam-macam produk berbahan jerami. 
Pemanfaatan jerami menjadi berbagai produk, untuk berbagai kategori sebagaimana disebutkan di atas untuk menghasilkan produk memerlukan proses produksi yang bermacam-macam baik yang bersifat sederhana maupun kompleks. Teknik produksi yang dapat diamati dari berbagai produk diatas yakni mulai dari potong sambung, anyam, lilit, ikat, tempel, pilin, serat, press/dipadatkan, cacah dan dilembutkan, kertas dan bubur kertas, dibakar diabu, warna dan pewarnaan. Uraian mengenai beberapa teknik produksi masal/terbatas di atas adalah sebagai berikut:

\section{- Anyam.}

Menganyam adalah pekerjaan menjalin rotan, bambu, pita dan bahan lainnya yang disusun dengan cara menyisipkan dan menumpangkan dengan berbeda arah (Tocharman, 2009). Seni anyam merupakan kebutuhan dasar paling kuno di daerah tropis sebagai kerajinan tangan bersifat alamiah dan keterampilan tradisional (Jasper \& Pirngadie, 2017). Bahan anyam yakni bahan alam yang terdapat dilingkungan alam sekitar. Anyam berdasarkan pada polanya terdiri dari anyaman jelujur dan anyaman penutup atau pinggiran (Saraswati, 2011). Anyaman jelujur membentuk lembaran atau bidang sebagaimana pada tikar maupun pada produk kerajinan lainnya. Anyaman penutup atau pinggiran berfungsi sebagai pengunci struktur atau penutup anyaman. Wayang jerami merupakan contoh penerapan atau gabungan pola ayam jelujur dan anyam penutup menjadi satu kesatuan.

- Ikat.

Upaya menghasilkan bentuk, ukuran dan panjang tertentu pengerjaan jerami dilakukan dengan diikat. Ikatan yang dimaksud baik dalam bentuk gulungan besar maupun sebatang jerami.

- Lilit dan pilin.

Kandungan lignin, selulusa dan pada bahan baku jerami sehingga jerami berbentuk memanjang dan berserat. Oleh karena itu jerami dapat dikerjakan dengan teknik lilit atau pilin. Pilin jerami yang memanjang sehingga membentuk tambang berukuran tertentu. Pada industri kerajinan dan mebel tambang mendong, enceng gondok, serat nanas, serat rami, termasuk jerami dan bahan alam lainnya merupakan bahan untuk produk kerajinan yang estetik dan alami.

- Tempel.

Teknik produksi pada industri kerajinan dan mebel berbahan jerami selanjutnya yang menarik dikaji sebagai dasar pengembangan desain adalah teknik tempel. Teknik tempel umum diaplikasikan untuk produk kerajinan dan mebel yang dan bersifat dekoratif. Teknik tempel dapat dilakukan dengan lem Aica Aibon, lem PVAc, lem Ethyl Cyanoarylate / lem Korea, lem Epoxy, dan lema Silicon.

- Potong sambung.

Potong dan sambung pada teknik produksi kerajinan dan mebel yang dimaksud dalam kondisi basah, kering maupun serat. Batang jerami yang berongga pada bagian dalamnya sehingga teknik sambung dapat dilakukan dengan memasukkan satu batang kebatang lainnya. Pada permukaan luar dengan diikat atau dipilin. Teknik sambung pada serat jerami adalah dengan dipilin untuk menghasilkan tambang jerami.

Serat.

Serat jerami dengan treathment tertentu sehingga dapat menjadi serat jerami untuk berbagai keperluan pembuatan produk kreatif. Serat jerami yang tidak beraturan sebagaimana pada serat nanas sehingga luaran yang dihasilkan yang paling direkomendasikan adalah tambang jerami. Serat jerami dengan tenun belum diketemukan.

Tenun.

Tenun merupakan teknik pembuatan kain yang sangat mengemuka. Teknik produksi dimana prinsipnya mengga-bungkan benang secara memanjang (lusi) dan melintang (pakan). Perkembangan selanjutnya tenun kemudian benang dipadukan dengan bahan-bahan lain, seperti lidi, rotan, dan jerami.

Jerami pada teknik tenun lebih bersifat pendukung sehingga berfungsi sebagai pakan saja pada proses pekerjaan tenun.

Press atau dipadatkan.

Teknik press pada industri pengolahan limbah kayu sangat populer dengan produk yang dihasilkan berupa papan partikel, MDF atau HDF. Teknik kempa untuk bahan baku jerami kekuatan sangat ditentukan oleh kepadatan dan ukuran atau kelembutan potongan jeraminya (Purwandaru, 2013). (Proctor, 2009) pemanfatan jerami sebagai bahan baku furnitur dengan menata dan dicover dengan plastik sebagai bentuk kepedulian terhadap lingkungan yakni sebagaimana dilakukan oleh Baley bench, Gusto Design.

- Cacah dan dilembutkan.

Jerami sebagai bahan baku kertas art paper. Tahapannya meliputi perebusan, pembersihan, penggilingan atau melumatkan, menyaring dan menyetak hingga kertas (Lopes, 2013).

- Susun.

Murah dan melimpahnya jerami, sehingga banyak 
karya seni yang berbahan jerami. Teknik produksi susun potong banyak menghasilkan karya seni berupa hewan, manusia dan produk lainnya. Di Banjarejo Kabupaten Grobogan bahkan terdapat event rutin yang disebut Festifal Jerami. Jerami diolah dan menjadi bentuk hewan dalam berbagai bentuk karya instalasi (Radar Kudus).

Pertimbangan selanjutnya jerami untuk berbagai produk kerajinan, mebel dan karya seni adalah warna dan tekstur jerami. Jerami berwarna kuning bersih, kuning keputihan, dan coklat muda sehingga jerami dimanfaatkan untuk karya seni dengan teknik tempel dengan mengeksplor perbedaan warna dari jerami. Kolase atau dengan dicat. Tekstur, jerami menjadi penciri bagi produk kerajinan maupun karya seni berbahan jerami. Tekstur jerami halus sekaligus berbulu pada bagian permukaan kulit jerami.

Karakteristik bahan, kemampuan keterampilan dan produksi masyarakat Indonesia dalam memanfaatkan jerami dalam pengembangan desain khususnya terkait dengan industri maka hal tersebut dapat sebagai dasar bagi perencanaan produk. Teknikteknik tersebut berkembang dan kuasai oleh masyarakat di berbagai daerah di Indonesia. Sebagai dasar pertimbangan dalam desain produk kerajinan dan mebel dalam pemanfaatan jerami sebagai limbah sisa pemanenan. Sebagai upaya pemanfaatan limbah sisa pemanenan padi dan upaya meningkatkan nilai manfaat, dan nilai ekonomi dari jerami.

\section{SIMPULAN}

Sebagai dasar bagi pengembangan produk, baik bersifat masal maupun terbatas. Pemanfaatan jerami sebagai karya seni, produk kerajinan maupun mebel dalam skala masal berpeluang dalam penyerapan pemanfaatan jerami dalam jumlah besar. Pemanfaatan jerami dalam jumlah banyak sehingga berpeluang mengurangi limbah, peningkatan nilai tambah dan nilai manfaat dari pada jerami. Pengembangan produk menjadi penting bagi pemanfataan limbah jerami, untuk riset lanjutan, terkait dengan desain, alat produksi dan keterampilan lanjutan dalam produksi berskala masal.

\section{DAFTAR PUSTAKA}

Jasper, J. E., \& Pirngadie, M. (2017). Seni Kerajinan Pribumi di Hindia Belanda (Anyaman, Vol. 1-1; M. Woworuntu, Penerj.). Jakarta: Dewan Kerajina Nasional Indonesia (Dekranas).

Kuswanto. (2007). Teknologi Pemrosesan Pengemedan dan Penyimpanan Benih. Yogyakarta: Kanisius.

Lopes, A. (2013). Pemanfaatan Jerami Padi (Oryza sativa) Menjadi Kertas Seni (Art paper) dan Produk Kerajinan [Skripsi]. Samarinda: Politeknik Negeri Pertanian Samarinda.

Proctor, R. (2009). 1000 new eco designs and where to find them. London: Lourence King Publishing Ltd.

Purwandaru, P. (2013). Pemanfaatan Jerami untuk Produk Ramah Lingkungan UKM Melalui Proses Kempa. Jurnal Teknik Lingkungan, 14, No. 2, 83-88.

Saraswati. (2011). Seri Membuat Handicarft Kreatif, Membuat Anyaman Hati Batang Rotan. Jakarta: Kemang Studio Angkasa.

Situmeang. (2010). Prospek Pengembangan Potensi Jerami di Indonesia [Penelitian]. Medan: Fakultas Teknik, Universitas Sumatera Utara.

Tocharman, M. (2009). Melestarikan Budaya Kriya Anyam [Workshop Anyaman dan Gerabah]. Bandung: Museum Sri Baduga Bandung.

https://radarkudus.jawapos.com/read/2019/09/26/ 157702/festival-jerami-banjarejo-bikingubernur-ganjar-berdecak-kagum 